\title{
Experimental and Theoretical Study of the Gas-phase Interaction Between Ionized Nitrile Sulfides and Pyridine
}

\author{
Pascal Gerbaux,* Yves Van Haverbeke, and Robert Flammang \\ Organic Chemistry Laboratory, University of Mons-Hainaut, Mons, Belgium
}

\begin{abstract}
The gas-phase reactivity of ionized nitrile sulfides, $\mathrm{R}-\mathrm{C} \equiv \mathrm{N}^{+}-\mathrm{S}^{*}$, towards neutral pyridine was studied both experimentally (six sector hybrid mass spectrometer) and theoretically (density functional theory and Møller-Plesset ab initio calculations). An ionized sulfur atom transfer and a cycloaddition process respectively yielding ionized pyridine $\mathrm{N}$-thioxide and a thiazolopyridinium cation were observed. Whereas the very efficient $\mathrm{S}^{*+}$ transfer reaction probably involves the intermediacy of several ion-molecule complexes, the thiazolopyridinium ion formation is likely to be initiated by an electrophilic attack of the $\mathrm{R}-\mathrm{C} \equiv \mathrm{N}^{+}-\mathrm{S}^{*}$ ion on the nitrogen atom of pyridine; the resulting intermediate then undergo an intramolecular substitution of an $\alpha$-hydrogen atom by the sulfur atom. (J Am Soc Mass Spectrom 2003, 14, 241-252) (c) 2003 American Society for Mass Spectrometry
\end{abstract}

$\mathrm{D}$ istonic ions are radical ions that have charge and radical sites located on different atoms. Positively-charged distonic ions have been the focus of intense gas-phase and computational research since the discovery in 1984 that these ions are surprisingly stable, and sometimes even more stable than their conventional counterparts [1,2]. It was also demonstrated that many conventional radical cations can isomerize into their distonic isomeric structures, spontaneously [3] or via the intermediacy of ion-molecule reactions [4]. Numerous other distonic ions have been purposely produced through complex $\mathrm{MS}^{\mathrm{n}}$ procedures to address several fundamental chemical questions [5].

Most of the associative ion-molecule reactions observed when the reactive ion is a distonic species involve a homolytic bond cleavage in the neutral reagent, leading to the abstraction of an atom or a radical by the ion. Many of these reactions are likely to be catalyzed by the charge site. Indeed, initial bond formation at the charge site stabilizes the collision complex and this bonding may also favorably position the neutral molecule for the subsequent radical reaction [6]. Transfer of charged odd-electron groups are also very common for distonic cations. For instance, ionized carbonyl ylide, ${ }^{\circ} \mathrm{CH}_{2}-\mathrm{O}-\mathrm{CH}_{2}^{+}$ions, generated by ionization-induced ring opening of oxirane [7], readily transfer an ionized methylene, $\mathrm{CH}_{2}^{+}$, to several nucleophilic molecules [8]. A recent study by Eberlin revealed that

Published online January 31, 2003

Address reprints to Pascal Gerbaux, Organic Chemistry Laboratory, University of Mons-Hainaut, 19 Avenue Maistriau, B-7000 Mons, Belgium. E-mail: pascal.gerbaux@umh.ac.be

*Postdoctoral researcher from the 'Fonds National pour la Recherche Scientifique' distonic acylium ions display, using appropriate neutral reagents, a rich dual reactivity; they react selectively as either free radicals with inert charge sites, or (and more pronouncedly) as acylium ions with inert radical sites. Such radical cations thus display, in a single molecule, dual free radical and ion reactivity [9]. In 1997, Eberlin also found out a third kind of reactions between distonic ions and neutral molecules, namely a 1,3-cycloaddition between ${ }^{\circ} \mathrm{CH}_{2}-\mathrm{O}-\mathrm{CH}_{2}^{+}$ions and carbonyl compounds [10]. This was the first cycloaddition reaction involving an ionized 1,3-dipole observed in the gas phase. More recently, we shown that the interaction between ionized nitrile oxides and several neutral nitriles allows the preparation of substituted azirinyl cations. This reaction was proposed to occur via cyclic intermediates such as ionized nitrosoazirines or ionized 1,2,4-oxadiazoles [11]. The bimolecular associative reactivity of the $\mathrm{R}-\mathrm{C} \equiv \mathrm{N}^{+}-\mathrm{X}^{*}$ ions $(\mathrm{X}=\mathrm{O}, \mathrm{S}$ and $\mathrm{Se})$ has been previously extensively studied and the observed reactions often consist in the transfer of the $\mathrm{X}^{\cdot+}$ group to the neutral molecule [12].Therefore, the azirinyl synthesis is an exception to the general reactivity of this kind of distonic ions.

Another peculiar reaction was observed when investigating the reaction between ionized nitrile sulfides and pyridine. Beside the always-dominant $\mathrm{S}^{*+}$ transfer, the interaction between $\mathrm{R}-\mathrm{C} \equiv \mathrm{N}^{+}-\mathrm{S}^{*}$ ions and pyridine also leads to an even-electron species corresponding to the addition of the ion to the neutral molecule, followed by the loss of one hydrogen atom. The gas-phase chemistry of ionized nitrile sulfides $\left(\mathrm{R}=\mathrm{CH}_{3}, \mathrm{Cl}\right.$ and $\mathrm{NC}$ ) with pyridine constitutes the subject of the present report. It has been experimentally investigated on a sector-quadrupole-sector hybrid mass spectrometer. A 
theoretical ab initio study has also been undertaken in order to support the experimentally derived conclusions.

\section{Experimental and Theoretical Methods}

\section{Methods}

The mass spectrometric experiments were performed on a large scale tandem mass spectrometer (Micromass AutoSpec 6F, Manchester, UK) having a c1E1B1c2E2c3c4E3B2c5E4 geometry, where E stands for electric sector, $\mathrm{B}$ for magnetic sector, and $\mathrm{c}$ for the collision cells [13]. Typical conditions were $8 \mathrm{kV}$ accelerating voltage, $1 \mathrm{~mA}$ emission current (in the chemical ionization mode), $200 \mu \mathrm{A}$ (in the electron ionization mode), and $70 \mathrm{eV}$ ionizing electron kinetic energy. The solid samples were introduced with a direct insertion probe, whereas the liquid samples were injected into the ion source via a heated septum inlet $\left(180{ }^{\circ} \mathrm{C}\right)$. This instrument has been modified with an rf-only quadrupole collision cell between $\mathrm{E}_{2}$ and $\mathrm{E}_{3}$ as reported elsewhere [13b]. This modification allows the study of associative ion-molecule reactions of decelerated ions having about $5 \mathrm{eV}$ kinetic energy. Briefly, the experiments utilizing the quadrupole consist of the selection of a beam of fast moving ions $(8000 \mathrm{eV})$ with the three first sectors and the deceleration of these ions to approximately $5 \mathrm{eV}$ before entering the quadrupole in order to maximize the yields of the associative ionmolecule reactions between the ions and the neutral reagent (pressure estimated to be $\mathrm{ca} 10^{-3}$ Torr). After reacceleration to $8000 \mathrm{eV}$, all the ions generated in the quadrupole cell are separated and mass-measured by scanning the field of the second magnet. The highenergy CA spectra of mass-selected ion-molecule reaction ionic products can be recorded by a linked scanning of the fields of the last three sectors (collision in $\mathrm{c}_{4}$ ) or by scanning the field of the last electric sector after mass-selection by the second magnet and collision in the fifth $\left(c_{5}\right)$ collision cell.

All the compounds considered in this work were commercially available and were used without any further purification, except 3,4-dicyano-1,2,5-thiadiazole that was prepared according to a procedure described in the literature [14].

\section{Calculations}

Standard $\mathrm{ab}$ initio and density functional theory calculations were performed using the GaussianW 98 suite of programs [15]. Geometries were optimized by density functional theory using Becke's hybrid functional (B3LYP) and the $6-31+G(d, p)$ basis set. Spin-unrestricted calculations were used for open-shell systems. Spin contamination in the UB3LYP calculation was small as judged from the $\left\langle\mathrm{S}^{2}\right\rangle$ operator expectation values that were $0.75-0.77$. The optimized structures were characterized by harmonic frequency analysis as local minima (all frequencies real). The B3LYP/6$31+G(d, p)$ frequencies were scaled by 0.963 and used to calculate zero-point vibrational energies (ZPE). Singlepoint energies were calculated at several levels of theory. In one set of calculations, MP2 and B3LYP energies were calculated with the larger 6-311+G(2df,p) basis set. Spin contamination in the UMP2 calculations was sometimes substantial. Spin annihilation using the Schlegel's projection method (PMP2) reduced the $\left.<\mathrm{S}^{2}\right\rangle$ values to $0.75-0.88$ for local minima [16]. The (P)MP2 energies were averaged with the B3LYP energies according to the empirical procedure that was introduced previously by Turecek et al. [17]. The so-denoted B3(P)MP2 scheme relies on cancellation of errors inherent to B3LYP and MP2 calculations. The theoretical background of this scheme was recently presented by Pople and co-workers [18]. Mulliken populations were obtained from B3LYP/6-31+G(d,p) calculations.

\section{Results and Discussion}

Pyridine $N$-thioxide radical cations $\left(\mathbf{1}^{\bullet+}\right)$ have been generated in the gas phase by reacting $\mathrm{CS}_{3}^{*+}$ radical cations with neutral pyridine either in the chemical ionization source or in the rf-only quadrupole cell installed on our six sectors instrument [19]. Radical cations $\mathbf{1}^{\cdot+}$ were differentiated from the isomeric mercaptopyridine molecular ions by collisional activation and associative ion-molecule reactions.

Ionized nitrile sulfide were also shown to be able to transfer an ionized sulfur atom to several neutral molecules, such as nitriles or nitric oxide [20]. In the present work, the bimolecular interaction between neutral pyridine and ionized cyanogen chloride sulfide, $\mathrm{Cl}-\mathrm{C} \equiv \mathrm{N}^{+}$$\mathrm{S}^{\bullet+}$, ionized cyanogen sulfide, $\mathrm{NC}-\mathrm{C} \equiv \mathrm{N}^{+}-\mathrm{S}^{*}$, or ionized acetonitrile sulfide, $\mathrm{CH}_{3}-\mathrm{C} \equiv \mathrm{N}^{+}-\mathrm{S}^{+}$, was attempted and was shown to predominantly lead to transfer of $\mathrm{S}^{{ }^{+}}$to the neutral reactant, yielding $\mathbf{1}^{\mathbf{+}}$ ions, see Scheme $\mathbf{1}$.

In addition, starting from $\mathrm{Cl}-\mathrm{C} \equiv \mathrm{N}^{+}-\mathrm{S}^{*}$ and $\mathrm{NC}$ $\mathrm{C} \equiv \mathrm{N}^{+}-\mathrm{S}^{\bullet}$ radical cations, other ion-molecule reaction products were also detected and formally correspond to (i) the transfers of respectively $\mathrm{Cl}^{+}$or $\mathrm{NC}^{+}$to neutral pyridine and to (ii) the addition of the ion to the neutral molecule, followed by the loss of an hydrogen atom, see Table 1.

\section{Ion-molecule Reactions Between $\mathrm{Cl}-\mathrm{C} \equiv \mathrm{N}^{+}-\mathrm{S}^{*}$ Radical Cations and Pyridine}

Mass-selected $m / z 93$ radical cations, ${ }^{35} \mathrm{Cl}-\mathrm{C} \equiv \mathrm{N}^{+}-\mathrm{S}^{*}$, prepared by dissociative ionization of 3,4-dichloro-1,2,5thiadiazole [21], react in the rf-only quadrupole cell with neutral pyridine by (i) charge exchange reaction ( $m / z$ 79, ionized pyridine), (ii) by $\mathrm{S}^{++}(\mathrm{m} / \mathrm{z} 111)$, (iii) $\mathrm{Cl}^{+}$ $\left(m / z\right.$ 114), (iv) $\mathrm{CNS}^{+}$( $m / z$ 137) transfers to pyridine, and (v) by addition of $\mathrm{ClCNS}^{+}$, followed by the loss of an hydrogen atom $(\mathrm{m} / \mathrm{z} 171)$, see Figure 1a and Table 1 . The $\mathrm{m} / \mathrm{z} 111$ and 114 products were easily identified on the 


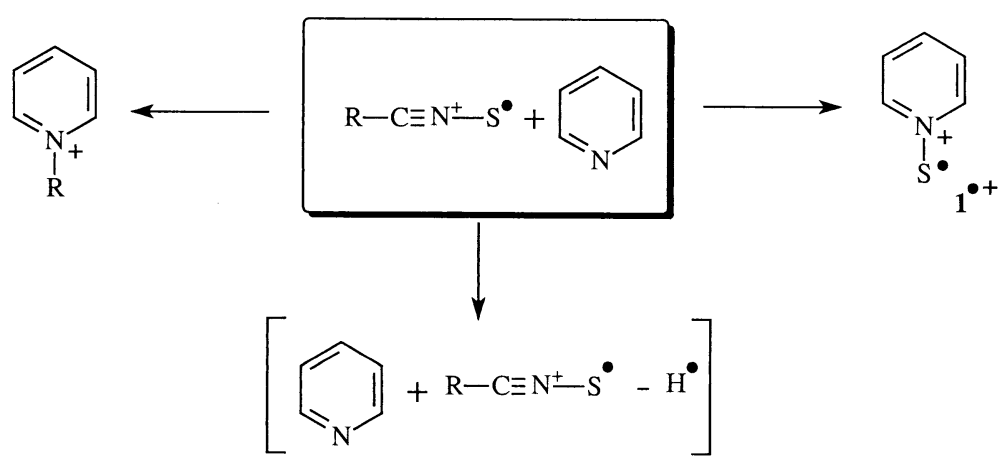

Scheme 1

basis of previous MS/MS studies, as their consecutive CA spectra were in keeping with the fragmentation expected for pyridine $N$-thioxide [19] and pyridine $N$-chloride [22]) molecular ions, respectively. $M / Z 67$ and 84 ions, also generated in the quadrupole, are respectively ionized pyrrole and thiophene and arise from unimolecular dissociations of pyridine thioxide ions [19].
The calculated ionization energy of cyanogen chloride sulfide (IE $=8.79$ ) [21] is significantly lower than the IE of pyridine $(9.25 \mathrm{eV})$ [23]. Therefore, the unexpected observation of the charge exchange reaction can be attributed to the lack of efficient thermalization of the reactive ions prior to the reaction. As suggested by a referee, ionization of pyridine could also come from its reaction with another ion than $\mathrm{ClCNS}^{*+}$. However, in

Table 1. Products of the associative ion-molecule reactions between $\mathrm{R}-\mathrm{C} \equiv \mathrm{N}^{+}-\mathrm{S}^{*}\left(\mathrm{R}=\mathrm{Cl}, \mathrm{NC}, \mathrm{CH}_{3}\right)$ and neutral pyridine

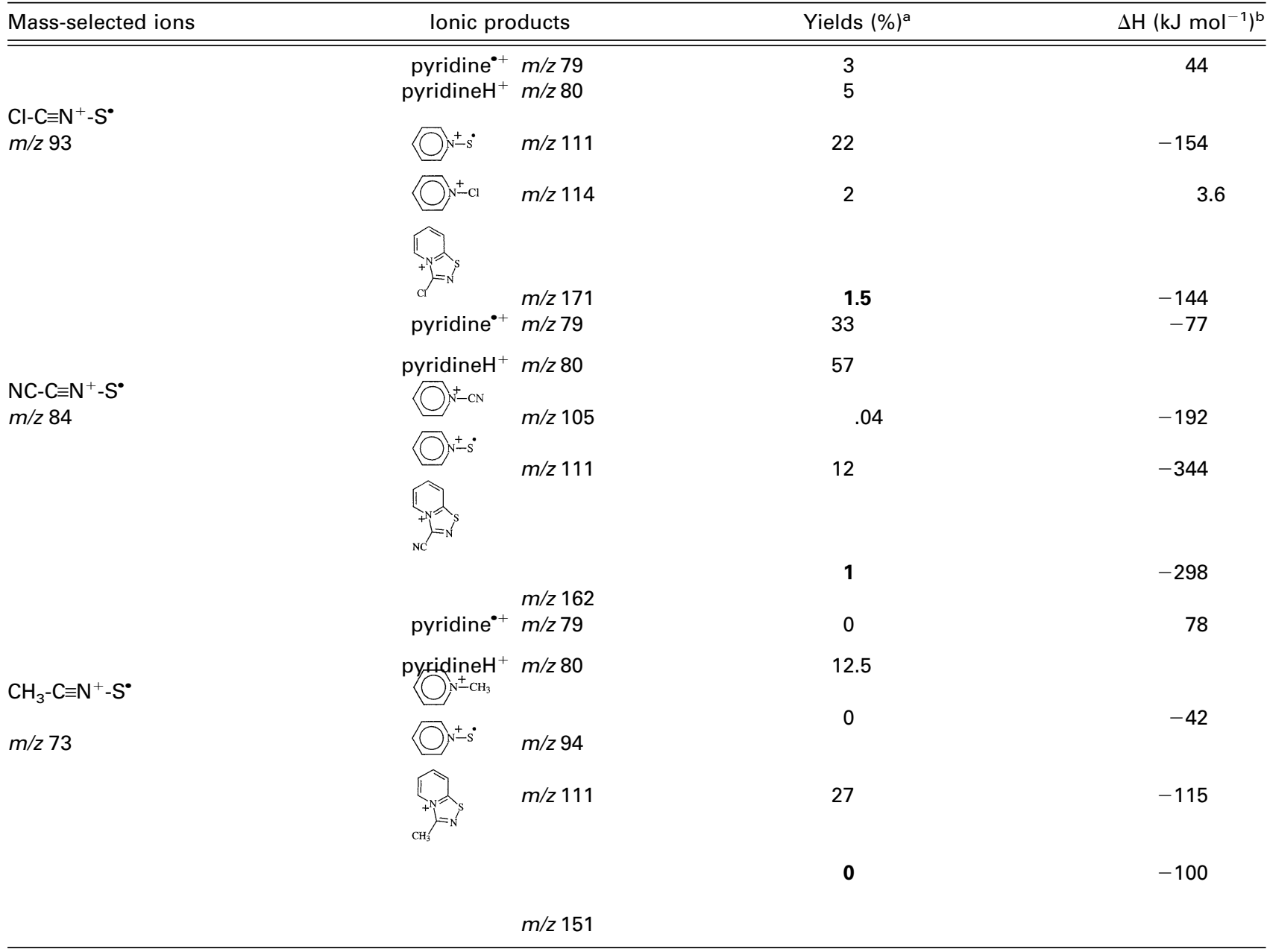

antensities relative to the main beam of reactants which was normalized to 100 units

bHeats of reaction calculated at the B3-(P)MP2 level of theory 


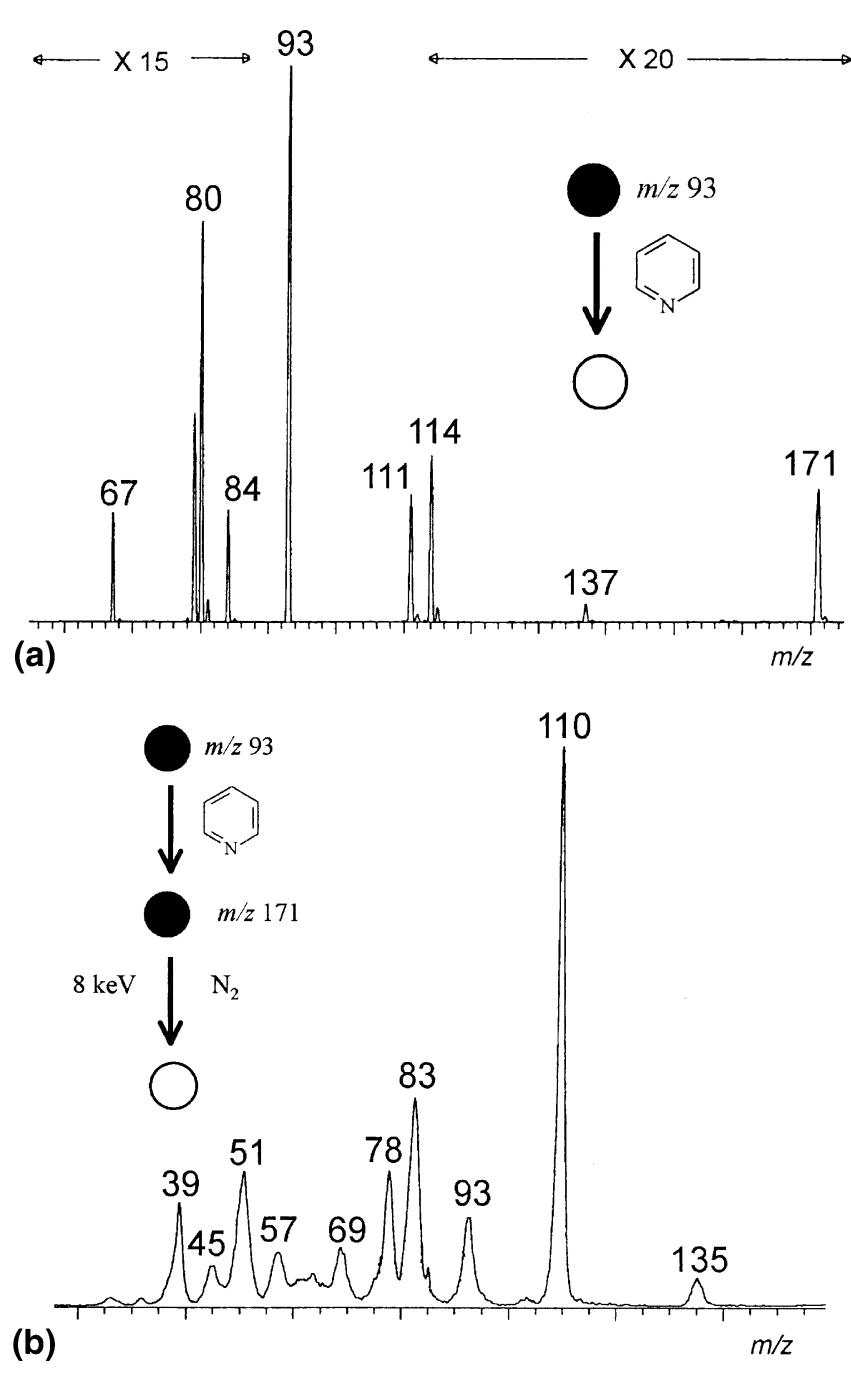

Figure 1. Associative ion-molecule reactions between mass-selected ${ }^{35} \mathrm{Cl}-\mathrm{C}=\mathrm{N}^{+}-\mathrm{S}^{*}(\mathrm{~m} / \mathrm{z}$ 93) and neutral pyridine in the quadrupole collision cell : (a) mass spectrum of the reaction products (B scan), and (b) consecutive CA spectrum (E scan, $8 \mathrm{keV}$ kinetic energy, $\mathrm{N}_{2}$ collision gas) of the $\mathrm{m} / \mathrm{z} 171$ ions. The terminology used to schematize the ion-molecule interactions is that introduced by Schwartz et al.: a filled circle represents a fixed (or selected) mass; an open circle, a variable (or scanned) mass, whereas the neutral reagent that causes the mass transition is shown between the circles [31].

order to confirm this assumption, we should calculate the recombination energies of all the ions present in the quadrupole and this is of course not the topic of the present work. Beside the charge exchange process, protonated pyridine $(\mathrm{m} / \mathrm{z} 80)$ was also produced. This protonation reaction, at first sight surprising as the mass-selected ions do not carry any hydrogen atom, probably results from the interaction between neutral pyridine and ionized pyridine generated in the charge exchange reaction. The same observation was also made by Eberlin when studying the interaction between $\mathrm{O}=\mathrm{C}=\mathrm{C}=\mathrm{N}^{+}=\mathrm{O}$ and pyridine. In that case, the signal corresponding to protonated pyridine was the most intense signal in the recorded double-stage product spectrum [24].

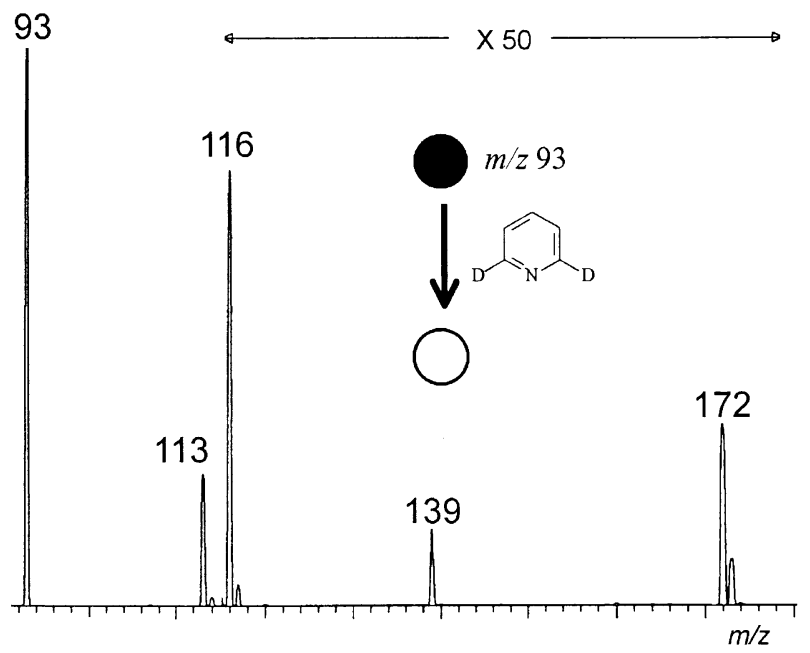

Figure 2. Associative ion-molecule reactions between mass-selected ${ }^{35} \mathrm{Cl}-\mathrm{C} \equiv \mathrm{N}^{+}-\mathrm{S}^{*}\left(\mathrm{~m} / \mathrm{z}\right.$ 93) and neutral pyridine- $\mathrm{d}_{2,6}$ in the quadrupole collision cell : mass spectrum of the reaction products (B scan).

The structure assignment of the $\mathrm{m} / \mathrm{z} 171$ ions is not straightforward because it is not possible to immediately derive the ionic structure on the basis of the CA spectrum alone (Figure $1 b$ ). It would be very instructive to unambiguously identify the leaving hydrogen atom and the use of pyridine- $\mathrm{d}_{2,6}$ could be very helpful in this context. The interaction between $\mathrm{ClCNS}^{\circ+}$ ions and the labeled pyridine was then performed in the quadrupole cell and the ion-molecule reaction products were observed at the mass-to-charge ratios expected on the basis of the labeling. Indeed, the signals were detected at $m / z 113,116$ and 139, for the $\mathrm{S}^{+}, \mathrm{Cl}^{+}$and $\mathrm{CNS}^{+}$ transfers, see Figure 2. As far as the $m / z 171$ cations are concerned, the corresponding signals are now observed at $m / z$ 172-173. Whereas the dominant $m / z 172$ signal corresponds to ions generated by addition of $\mathrm{ClCNS}^{+}$ ions to labeled pyridine followed by the loss of a deuterium atom, the loss of an hydrogen atom gives rise to the less intense $m / z 173$ signal. Because the ratio $\mathrm{m} / \mathrm{z} 172 / \mathrm{m} / \mathrm{z} 173(=4.0)$ has to be corrected for the isotopic contribution of the $\mathrm{m} / \mathrm{z} 172$ signal (about 5\%) and because it is expected that the loss of $\mathrm{D}^{\circ+}$, compared to the loss of $\mathrm{H}^{++}$, could be affected by a significant kinetic isotopic effect, it seems reasonable to assume that the loss of an hydrogen atom from the addition product between $\mathrm{ClCNS}^{+}$and pyridine selectively involves the hydrogens 2 and 6 of the pyridine ring. This is confirmed by the investigation, in the CI source, of the interactions between $\mathrm{ClCNS}^{+}$ions and 2-picoline (2-methylpyridine), 2,6-lutidine (2,6-dimethylpyridine), and 2(3)-bromopyridines. Indeed, a methyl radical is lost from the encounter complex between 2-picoline or 2,6-lutidine and the reactive ions, whereas the addition product between 2-bromopyridine and $\mathrm{ClCNS}^{-+}$ions only expels a bromine atom. On the other hand, the loss of an hydrogen atom is observed when the neutral molecule is 3 -bromopyridine. 


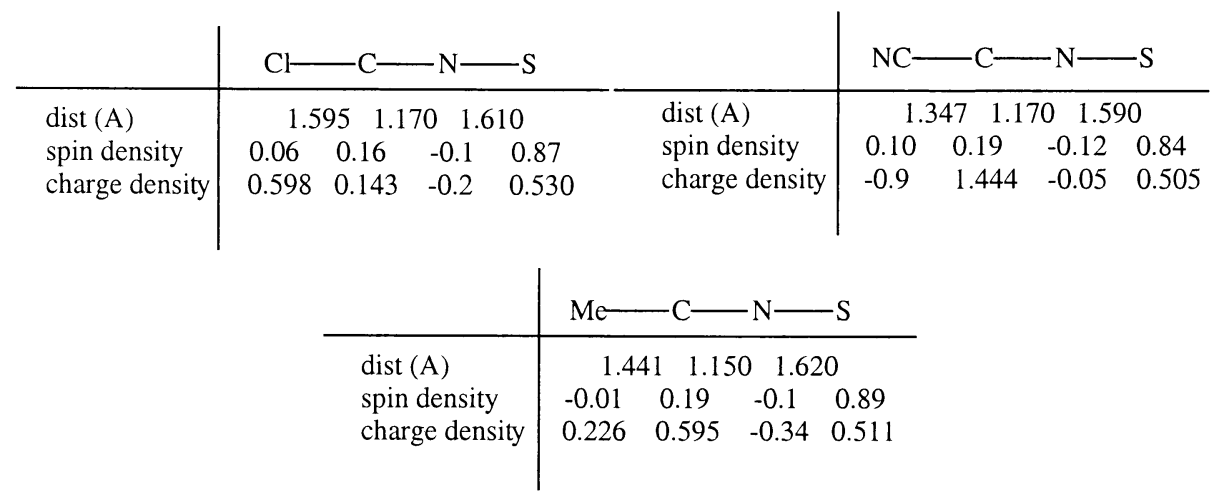

Scheme 2

Pyridine has already been used to investigate the chemistry of distonic ions, such as ${ }^{\circ} \mathrm{CH}_{2}-\mathrm{O}-\mathrm{CH}_{2}^{+}$ions [8, 25]. This interaction was shown to yield 1-methylenepyridinium ion via a reaction pathway requiring no energy barrier. In the same vein, Kenttämaa et al. [6b] recently demonstrated that the electrophilic addition of a cation to a lone electronic pair of a nucleophilic molecule is a barrierless process, whereas a radical addition requires unpairing the lone pair of electrons and thus involves a barrier. In the case of distonic ions (ion + radical), that means that such an addition reaction preferentially occurs at the charge site rather than at the radical site, provided there is no coordinative saturation at the charge site. As far as ionized nitrile sulfides are concerned, prior to discussing the reaction mechanisms, we have to establish the charge distribution of the ions in order to check the chemical availability of the charge sites. Therefore, we optimized the geometries of the three reactive ions used in this work by performing ab initio calculations at the B3LYP/6$31+\mathrm{G}(\mathrm{d}, \mathrm{p})$ level of theory. The results are presented in Scheme 2. From these calculations, it is immediately concluded that $\mathrm{R}-\mathrm{C}^{+}=\mathrm{N}-\mathrm{S}^{*}$ can be considered as one of the best descriptions of the reality because (i) the spin density of the ions is concentrated on the sulfur atom, (ii) there is no positive charge on the nitrogen atom, (iii) the $\mathrm{C}-\mathrm{N}$ bonds are longer than a regular $\mathrm{C} \equiv \mathrm{N}$ triple bond (1.161 $\AA$, calculated for acetonitrile at the same level of theory) but shorter than a $\mathrm{C}=\mathrm{N}$ double bond (1.272 $\AA$, calculated for $\mathrm{H}_{2} \mathrm{C}=\mathrm{N}-\mathrm{H}$ at the same level of theory), and finally, (iv) the N-S bonds are longer than a regular $\mathrm{N}=\mathrm{S}$ double bond $(1.580 \AA$, calculated for $\mathrm{H}-\mathrm{N}=\mathrm{S}$ at the same level of theory) but shorter than a $\mathrm{N}-\mathrm{S}$ single bond (1.741 $\AA$, calculated for $\mathrm{NH}_{2}-\mathrm{SH}$ at the same level of theory). There is thus no coordinative saturation at the charge site. Such a situation would have been concluded for the $\mathrm{R}-\mathrm{C} \equiv \mathrm{N}^{+}-\mathrm{S}^{\cdot}$ mesomeric structure. Nevertheless, the positive charge density is also very important on the sulfur atom, see Scheme 2. That means that, together with the positive-charged carbon atom described by the $\mathrm{R}^{-\mathrm{C}^{+}}=\mathrm{N}-\mathrm{S}^{*}$ mesomeric structure, the sulfur atom represents another highly reactive electrophilic center. The ionized sulfur transfer reaction can then be explained on the basis of an initial sharing of $S^{\cdot+}$ by both the nucleophilic species, pyridine and cyanogen chloride, see Figure 3 and Scheme $3 a$.

The reaction leading to $m / z 171$ ions is likely to be initiated by an electrophilic attack of the distonic ion on the lone electronic pair of pyridine, leading to a C-N bond formation, see Scheme $\mathbf{3 b}$. Such a bonding has been already described since the addition of $\left(\mathrm{O}=\mathrm{C}=\mathrm{N}^{+}=\mathrm{C}=\mathrm{O} \leftrightarrow \mathrm{O}=\mathrm{C}^{+}-\mathrm{N}=\mathrm{C}=\mathrm{O}\right)$ to pyridine leads to the [pyridine- $\mathrm{C}(\mathrm{NCO})=\mathrm{O}^{+}$cation [24]. The intermediate ion can then develop, via a radicalar substitution of an $\alpha$-hydrogen atom by the sulfur radical, towards a bicyclic thiazolopyridinium cation, $2^{+}$. The initial bonding at the pyridine ring nitrogen atom would explain the selectivity of the leaving hydrogen atom. A quite similar mechanism, involving an initial bonding at the charge site followed by a radicalar reaction, was proposed by Kenttämaa to explain the reactivity of ${ }^{\circ} \mathrm{CH}_{2} \mathrm{CH}_{2} \mathrm{CH}_{2} \mathrm{C}^{+}=\mathrm{O}$ distonic ion with several neutral reagents such as dimethyl disulfide, acetone, acetic acid and alkyl iodides [26].

The CA spectrum (Figure $1 \mathrm{~b}$ ) of the $m / z 171$ ions can thus be considered on the basis of the proposed structure, $2^{+}$. The main decomposition pathways lead to (i) the loss of cyanogen chloride giving pyridine-2-thiyl cations $(\mathrm{m} / \mathrm{z} 110)$, (ii) the formation of $\mathrm{ClCNS}^{*+}(\mathrm{m} / \mathrm{z}$ 93), and (iii) the loss of ClCNS $(\mathrm{m} / z$ 78). The formation of pyridine-2-thiyl cations $(\mathrm{m} / \mathrm{z} 110)$, characteristic of the $2^{+}$structure and in particular of the C-S bonding, is corroborated by the presence of some ions arising from consecutive dissociations of these $\mathrm{m} / \mathrm{z} 110$ cations, the corresponding signals are detected at $\mathrm{m} / \mathrm{z} 83$ (loss of $\mathrm{HCN}), m / z 69,57,51,45$ and 39. All these peaks are also observed in the CA spectrum of authentic pyridine-2thiyl cations, obtained in the EI source by loss of an hydrogen atom from the molecular ions of 2-mercaptopyridine. The production of the thiazolopyridinium cation, $2^{+}$, also find some support from theoretical calculations since the investigation of its geometry, at the B3LYP / 6-31+G(d,p) level of theory, reveals that the bicyclic planar structure, depicted in Figure 4 , is a minimum on the energy surface.

A theoretical approach of the reactions leading to $\mathrm{m} / \mathrm{z}$ 


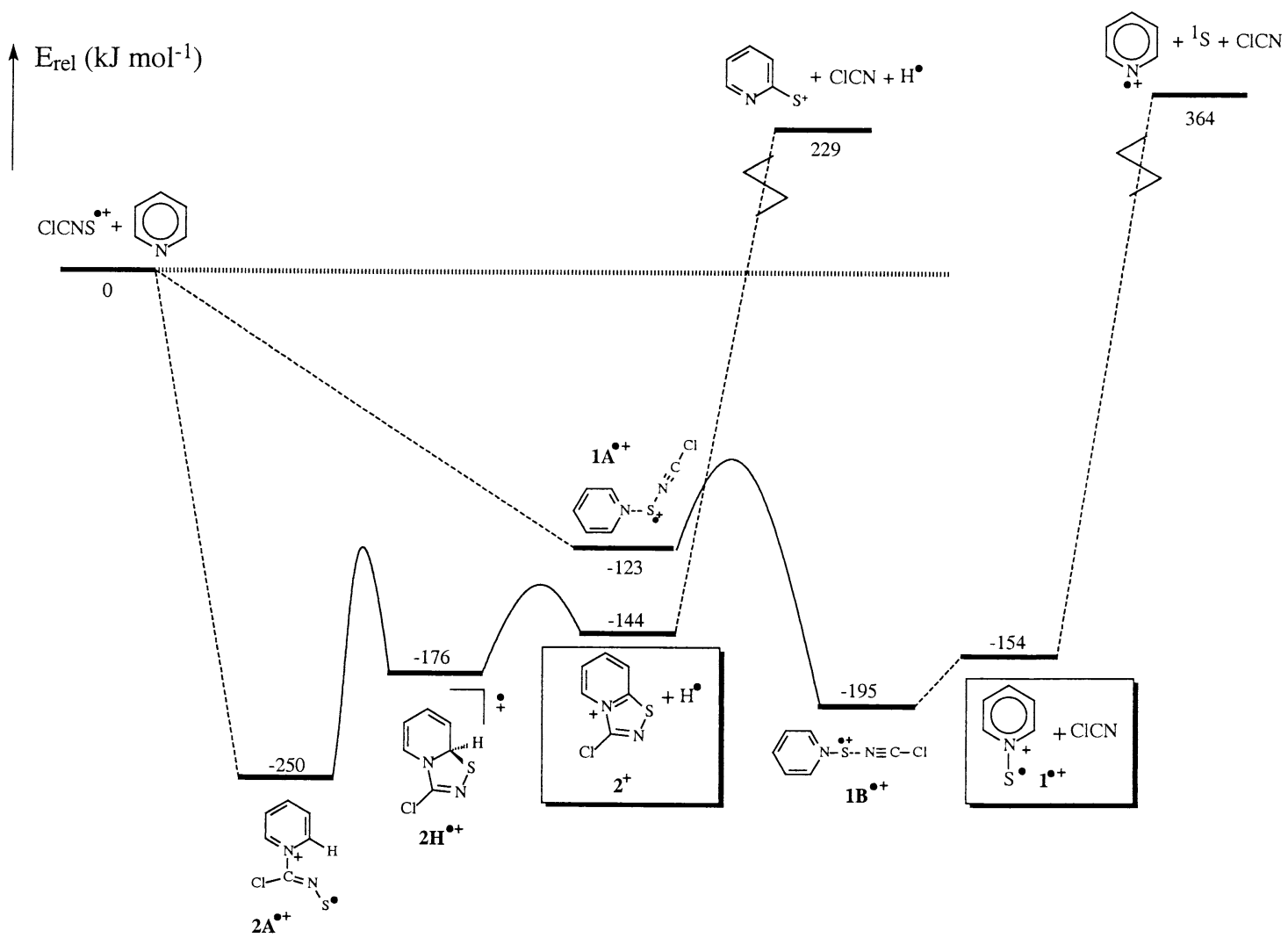

Figure 3. $\mathrm{B} 3 \mathrm{LYP} / 6-31+\mathrm{G}(\mathrm{d}, \mathrm{p})$ potential energy diagram for the $\mathrm{ClCNS}^{*+}$ pyridine interaction. Relative energies are given in $\mathrm{kJ} \mathrm{mol}^{-1}$.

111 and 171 ions, see Scheme 3, is presented in Figure 3; all the energetic data being summarized in Table 2. First of all, these processes were calculated to be exothermic, respectively $-154 \mathrm{~kJ} \mathrm{~mol}^{-1}$ and $-144 \mathrm{~kJ} \mathrm{~mol}^{-1}$ for the reactions leading to pyridine- $\mathrm{S}^{++}\left(\mathbf{1}^{++}\right)$and thiazolopyridinium ions $\left(2^{+}\right)$. These findings are of course totally in keeping with the observation of the corresponding products, since exothermic reactions are always favored in the gas phase. In addition, at the level of theory used in this work, we have identified plausible intermediates on the way to these ion-molecule reactions products. First, the thiazolopyridinium cation, $\mathbf{2}^{+}$, can be generated via the intermediacy of a bicyclic compound, $\mathbf{2} \mathbf{H}^{\mathbf{}}$, simply resulting from the addition of $\mathrm{ClCNS}^{+}$to pyri-

(a)

Ionized sulfur atom transfer reaction

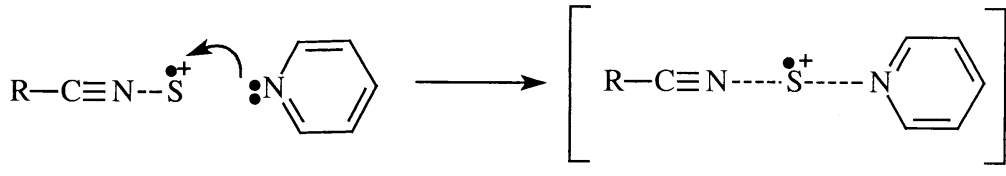

Addition-hydrogen-atom-loss reaction

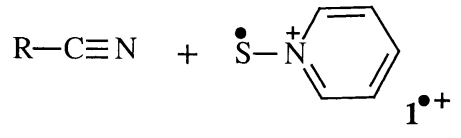

(b)

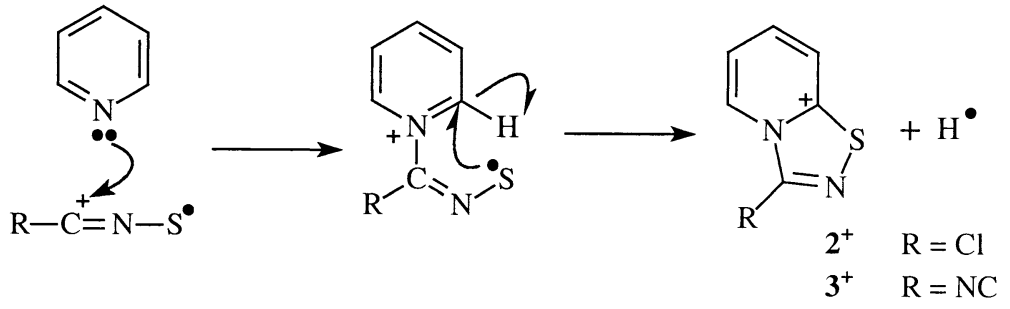

Scheme 3 

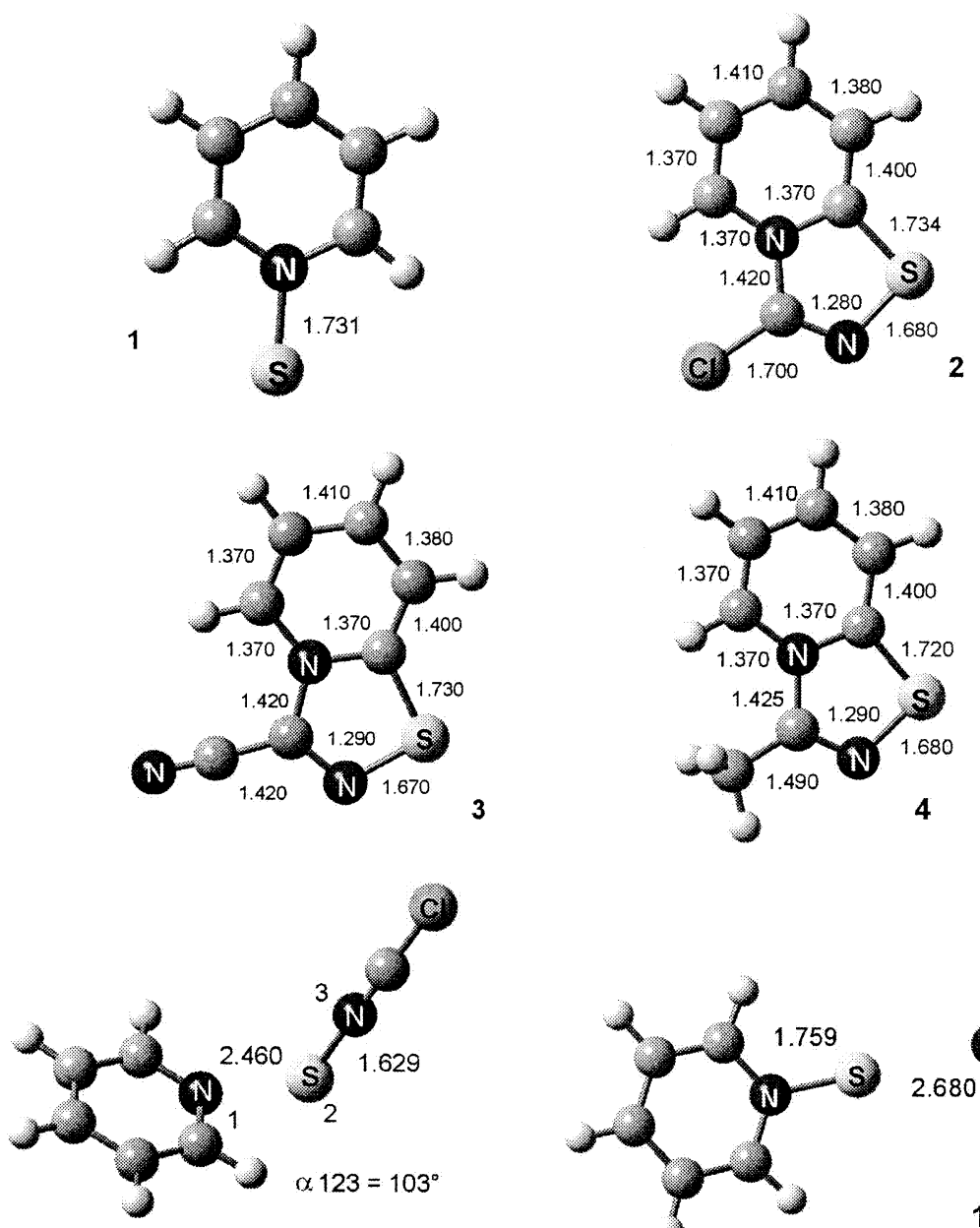

$1 \mathrm{~A}$
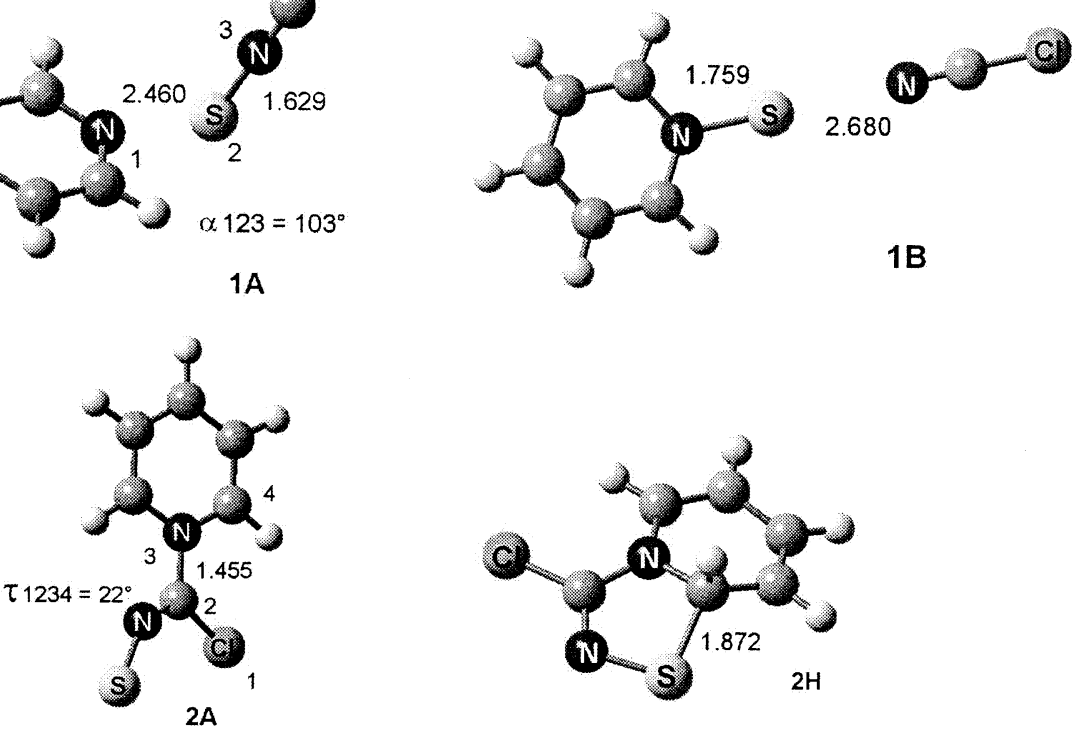

Figure 4. B3LYP/6-31+G(d,p) optimized geometries. Bond distances are given in angstroms and angles in degrees.

dine and subsequent ring closure by S-C bond formation but without the loss of the hydrogen atom. These non-planar bicyclic ions, $2 \mathrm{H}^{++}$, are located $32 \mathrm{~kJ} \mathrm{~mol}^{-1}$ below the thiazolopyridinium cations (plus an hydrogen atom). The initial adduct between pyridine and $\mathrm{Cl}-\mathrm{C} \equiv \mathrm{N}^{+}-\mathrm{S}^{*}, 2 \mathrm{~A}^{\cdot+}$, is also calculated to be a local minimum on the potential energy surface, lying at $-250 \mathrm{~kJ}$ $\mathrm{mol}^{-1}$ below the reactants. The different transition states were not approached in the present work and the heights of their representations in Figure 3 cannot be taken into account.

The dominant ionized sulfur atom transfer reaction can be described by a double-well potential curve as shown in Figure 3. The first ion-molecule complex, $\mathbf{1 A}^{\cdot+}$, presents some interesting geometrical information, see Figure 4: (i) the angle between the pyridine ring and the $\mathrm{ClCNS}$ linear species amounts to $103^{\circ}$, (ii) the N-S bond in the $\mathrm{Cl}-\mathrm{C} \equiv \mathrm{N}-\mathrm{S}$ moiety is somewhat longer than in the isolated ion, from 1.610 to $1.629 \AA$, and (iii) the N-S bond involving the nitrogen of the pyridine ring is much more longer, $2.460 \AA$, than in pyridine $N$-thioxide ions $(1.731 \AA)$. The second complex, $1 \mathbf{B}^{\cdot+}$, obviously represents the consecutive step in the $\mathrm{S}^{*+}$ transfer to pyridine with a longer $\mathrm{N}(\mathrm{ClCNS})-\mathrm{S}$ 
Table 2. Total energies (Hartree) and ZPE $\left(\mathrm{kJ} \mathrm{mol}^{-1}\right)$ at different levels of theory of the ionic and neutral species involved in the reactions under study

\begin{tabular}{|c|c|c|c|}
\hline Species & Method & $E_{\text {tot }}$ & ZPE \\
\hline \multicolumn{4}{|c|}{ Reactive species } \\
\hline $\mathrm{CICNS}^{\bullet+}$ & Opt : B3LYP/6-31+G(d,p) & -950.8432639 & 28.7107 \\
\hline $\mathrm{CICNS}^{\bullet+}$ & SP : PMP2/6-311+G(2df,p) & -949.686783 & - \\
\hline $\mathrm{ClCNS}^{\bullet+}$ & $\mathrm{SP}: \mathrm{B} 3 \mathrm{LYP} / 6-311+\mathrm{G}(2 \mathrm{df}, \mathrm{p})$ & -950.9418457 & - \\
\hline $\mathrm{ClCNS}^{\bullet+}$ & B3-PMP2 & -950.3143144 & - \\
\hline $\mathrm{NCCNS}^{\bullet+}$ & Opt : B3LYP/6-31+G(d,p) & -583.541469 & 48.0026 \\
\hline $\mathrm{NCCNS}^{\bullet+}$ & SP : PMP2/6-311+G(2df,p) & -582.547631 & - \\
\hline $\mathrm{NCCNS}^{\bullet+}$ & SP : B3LYP/6-311+G(2df,p) & -583.549166 & - \\
\hline $\mathrm{NCCNS}^{\bullet+}$ & B3-PMP2 & -583.0483984 & - \\
\hline $\mathrm{CH}_{3} \mathrm{CNS}^{\bullet+}$ & Opt : B3LYP/6-31+G(d,p) & -530.610853 & 122.8731 \\
\hline $\mathrm{CH}_{3} \mathrm{CNS}^{\bullet+}$ & $\mathrm{SP}: \mathrm{PMP} 2 / 6-311+\mathrm{G}(2 \mathrm{df}, \mathrm{p})$ & -529.8325102 & - \\
\hline $\mathrm{CH}_{3} \mathrm{CNS}^{\bullet+}$ & SP : B3LYP/6-311+G(2df,p) & -530.6811648 & - \\
\hline $\mathrm{CH}_{3} \mathrm{CNS}^{\bullet+}$ & B3-PMP2 & -530.2568375 & - \\
\hline Pyridine & Opt : B3LYP/6-31+G(d,p) & -248.3033647 & 232.9507 \\
\hline Pyridine & $\mathrm{SP}: \mathrm{MP} 2 / 6-311+\mathrm{G}(2 \mathrm{df}, \mathrm{p})$ & -247.7364353 & - \\
\hline Pyridine & $S P: B 3 L Y P / 6-311+G(2 d f, p)$ & -248.3647857 & - \\
\hline $\begin{array}{l}\text { Pyridine } \\
\text { lon-molecule r }\end{array}$ & \multicolumn{2}{|c|}{ lon-molecule reactions products } & - \\
\hline $\mathrm{ClCN}$ & Opt : B3LYP/6-31+G(d,p) & -553.0139133 & 22.838 \\
\hline $\mathrm{CICN}$ & $\mathrm{SP}: \mathrm{MP} 2 / 6-311+\mathrm{G}(2 \mathrm{df}, \mathrm{p})$ & -552.3440422 & - \\
\hline $\mathrm{CICN}$ & $S P: B 3 L Y P / 6-311+G(2 d f, p)$ & -553.0767826 & - \\
\hline $\mathrm{CICN}$ & B3-MP2 & -552.7104124 & - \\
\hline $\mathrm{NCCN}$ & Opt : B3LYP/6-31+G(d,p) & -185.662098 & 43.3555 \\
\hline $\mathrm{NCCN}$ & $\mathrm{SP}: \mathrm{MP} 2 / 6-311+\mathrm{G}(2 \mathrm{df}, \mathrm{p})$ & -185.316908 & - \\
\hline $\mathrm{NCCN}$ & $\mathrm{SP}: \mathrm{B} 3 \mathrm{LYP} / 6-311+\mathrm{G}(2 \mathrm{df}, \mathrm{p})$ & -185.717852 & - \\
\hline NCCN & B3-MP2 & -185.5173796 & - \\
\hline $\mathrm{CH}_{3} \mathrm{CN}$ & Opt : B3LYP/6-31+G(d,p) & -132.7658135 & 118.88 \\
\hline $\mathrm{CH}_{3} \mathrm{CN}$ & $\mathrm{SP}: \mathrm{MP} 2 / 6-311+\mathrm{G}(2 \mathrm{df}, \mathrm{p})$ & -132.475481 & - \\
\hline $\mathrm{CH}_{3} \mathrm{CN}$ & $\mathrm{SP}: \mathrm{B} 3 \mathrm{LYP} / 6-311+\mathrm{G}(2 \mathrm{df}, \mathrm{p})$ & -132.8024651 & - \\
\hline $\mathrm{CH}_{3} \mathrm{CN}$ & B3-MP2 & -132.6389731 & - \\
\hline $1^{++}$ & Opt : B3LYP/6-31+G(d,p) & -646.1925851 & 240.5869 \\
\hline $1^{\bullet+}$ & $\mathrm{SP}: \mathrm{PMP} 2 / 6-311+\mathrm{G}(2 \mathrm{df}, \mathrm{p})$ & -645.1417925 & - \\
\hline $1^{\bullet+}$ & $\mathrm{SP}: \mathrm{B} 3 \mathrm{LYP} / 6-311+\mathrm{G}(2 \mathrm{df}, \mathrm{p})$ & -646.2856721 & - \\
\hline $1^{\bullet+}$ & B3-PMP2 & -645.7137323 & - \\
\hline Pyridine- $\mathrm{Cl}^{+}$ & Opt : B3LYP/6-31+G(d,p) & -708.2067401 & 241.0147 \\
\hline Pyridine- $\mathrm{Cl}^{+}$ & $\mathrm{SP}: \mathrm{MP} 2 / 6-311+\mathrm{G}(2 \mathrm{df}, \mathrm{p})$ & -707.1471873 & - \\
\hline Pyridine- $\mathrm{Cl}^{+}$ & $\mathrm{SP}: \mathrm{B} 3 \mathrm{LYP} / 6-31+\mathrm{G}(2 \mathrm{df}, \mathrm{p})$ & -708.3027578 & - \\
\hline Pyridine- $\mathrm{Cl}^{+}$ & B3-MP2 & -707.7249726 & - \\
\hline Pyridine- $\mathrm{CN}^{+}$ & Opt : B3LYP/6-31+G(d,p) & -340.857255 & 262.3937 \\
\hline Pyridine- $\mathrm{CN}^{+}$ & $\mathrm{SP}: \mathrm{MP} 2 / 6-311+\mathrm{G}(2 \mathrm{df}, \mathrm{p})$ & -340.12213 & - \\
\hline Pyridine- $\mathrm{CN}^{+}$ & $\mathrm{SP}: \mathrm{B} 3 \mathrm{LYP} / 6-311+\mathrm{G}(2 \mathrm{df}, \mathrm{p})$ & -340.946326 & - \\
\hline Pyridine- $\mathrm{CN}^{+}$ & B3-MP2 & -340.5342282 & - \\
\hline Pyridine- $\mathrm{CH}_{3}{ }^{+}$ & Opt : B3LYP/6-31+G(d,p) & -287.9905455 & 20.1217 \\
\hline Pyridine- $\mathrm{CH}_{3}{ }^{+}$ & $\mathrm{SP}: \mathrm{MP} 2 / 6-311+\mathrm{G}(2 \mathrm{df}, \mathrm{p})$ & -287.3143303 & - \\
\hline Pyridine- $\mathrm{CH}_{3}{ }^{+}$ & $\mathrm{SP}: \mathrm{B} 3 \mathrm{LYP} / 6-311+\mathrm{G}(2 \mathrm{df}, \mathrm{p})$ & -288.0602266 & - \\
\hline Pyridine- $\mathrm{CH}_{3}{ }^{+}$ & B3-MP2 & -287.6872785 & - \\
\hline CNS & Opt : B3LYP/6-31+G(d,p) & -490.9448876 & 20.1217 \\
\hline CNS & $\mathrm{SP}: \mathrm{PMP} 2 / 6-311+\mathrm{G}(2 \mathrm{df}, \mathrm{p})$ & -490.2725962 & - \\
\hline CNS & SP : B3LYP/6-311+G(2df,p) & -491.0042104 & - \\
\hline CNS & B3-PMP2 & -490.6384033 & - \\
\hline $\mathbf{2}^{+}$ & Opt : B3LYP/6-31+G(d,p) & -1198.679385 & 245.63 \\
\hline $2^{+}$ & $\mathrm{SP}: \mathrm{MP} 2 / 6-311+\mathrm{G}(2 \mathrm{df}, \mathrm{p})$ & -1196.98764 & - \\
\hline $2^{+}$ & $\mathrm{SP}: \mathrm{B} 3 \mathrm{LYP} / 6-311+\mathrm{G}(2 \mathrm{df}, \mathrm{p})$ & -1198.837925 & \\
\hline $2^{+}$ & B3-MP2 & -1197.912932 & - \\
\hline $3^{+}$ & Opt : B3LYP/6-31+G(d,p) & -831.31411 & 266.23 \\
\hline $3^{+}$ & $\mathrm{MP} 2 / 6-311+\mathrm{G}(2 \mathrm{df}, \mathrm{p})$ & -829.947202 & - \\
\hline $3^{+}$ & $\mathrm{SP}: \mathrm{B} 3 \mathrm{LYP} / 6-311+\mathrm{G}(2 \mathrm{df}, \mathrm{p})$ & -931.465439 & - \\
\hline $3^{+}$ & B3-MP2 & -830.7063205 & - \\
\hline $4^{+}$ & Opt : B3LYP/6-31+G(d,p) & -778.4295945 & 343.6781 \\
\hline $4^{+}$ & $\mathrm{SP}: \mathrm{MP} 2 / 6-311+\mathrm{G}(2 \mathrm{df}, \mathrm{p})$ & -777.1181214 & - \\
\hline $4^{+}$ & $\mathrm{SP}: \mathrm{B} 3 \mathrm{LYP} / 6-311+\mathrm{G}(2 \mathrm{df}, \mathrm{p})$ & -778.5618271 & - \\
\hline $4^{+}$ & B3-MP2 & -777.8399743 & - \\
\hline $\mathrm{H}^{\cdot}$ & Opt : B3LYP/6-31+G(d,p) & -0.5002728 & $\begin{array}{c}0 \\
\text { (continued) }\end{array}$ \\
\hline
\end{tabular}


Table 2. (continued)

\begin{tabular}{|c|c|c|c|}
\hline Species & Method & $E_{\text {tot }}$ & ZPE \\
\hline $\mathrm{H}^{\circ}$ & SP : PMP2/6-311+G(2df,p) & -0.4998098 & - \\
\hline $\mathrm{H}^{-}$ & SP : B3LYP/6-311+G(2df,p) & -0.5021559 & - \\
\hline $\mathrm{H}^{\cdot}$ & B3-PMP2 & -0.50098285 & - \\
\hline \multicolumn{4}{|c|}{ Intermediate species in the $\mathrm{CICNS}^{\bullet+}$ /pyridine reactions } \\
\hline $1 A^{\cdot+}$ & Opt : B3LYP/6-31+G(d,p) & -1199.197558 & 263.9247 \\
\hline $1 A^{\cdot+}$ & $\mathrm{SP}: \mathrm{PMP} 2 / 6-311+\mathrm{G}(2 \mathrm{df}, \mathrm{p})$ & -1197.46863 & - \\
\hline $1 A^{\cdot+}$ & SP : B3LYP/6-311+G(2df,p) & -1199.356505 & - \\
\hline $1 A^{\cdot+}$ & B3-PMP2 & -1198.412584 & - \\
\hline $1 \mathrm{~B}^{\cdot+}$ & Opt : B3LYP/6-31+G(d,p) & -1199.221603 & 265.3376 \\
\hline $1 \mathrm{~B}^{\cdot+}$ & $\mathrm{SP}: \mathrm{PMP} 2 / 6-311+\mathrm{G}(2 \mathrm{df}, \mathrm{p})$ & -1197.502872 & - \\
\hline $1 \mathrm{~B}^{\cdot+}$ & $\mathrm{SP}: \mathrm{B} 3 \mathrm{LYP} / 6-311+\mathrm{G}(2 \mathrm{df}, \mathrm{p})$ & -1199.378127 & - \\
\hline $1 \mathrm{~B}^{\cdot+}$ & B3-PMP2 & -1198.440499 & - \\
\hline $2 A^{\cdot+}$ & Opt : B3LYP/6-31+G(d,p) & -1199.249409 & 272.9873 \\
\hline $2 A^{\cdot+}$ & SP : PMP2/6-311+G(2df,p) & -1197.524716 & - \\
\hline $2 A^{\circ+}$ & $\mathrm{SP}: \mathrm{B} 3 \mathrm{LYP} / 6-311+\mathrm{G}(2 \mathrm{df}, \mathrm{p})$ & -1199.40403 & - \\
\hline $2 A^{\cdot+}$ & B3-PMP2 & -1198.464373 & - \\
\hline $2 \mathrm{H}^{\bullet+}$ & Opt : B3LYP/6-31+G(d,p) & -1199.217688 & 268.7556 \\
\hline $2 \mathrm{H}^{\circ+}$ & $\mathrm{SP}: \mathrm{PMP} 2 / 6-311+\mathrm{G}(2 \mathrm{df}, \mathrm{p})$ & -1197.495878 & - \\
\hline $2 \mathrm{H}^{\cdot+}$ & $S P: B 3 L Y P / 6-311+G(2 d f, p)$ & -1199.373859 & - \\
\hline $2 \mathrm{H}^{\circ+}$ & B3-PMP2 & -1198.434868 & - \\
\hline \multicolumn{4}{|c|}{ Fragments of ion-molecule reactions products } \\
\hline Pyridine-2-thyil & Opt : B3LYP/6-31+G(d,p) & -645.5297689 & 205.3835 \\
\hline Pyridine-2-thyil & $\mathrm{SP}: \mathrm{MP} 2 / 6-311+\mathrm{G}(2 \mathrm{df}, \mathrm{p})$ & -644.48619 & - \\
\hline Pyridine-2-thyil & $\mathrm{SP}: \mathrm{B} 3 \mathrm{LYP} / 6-311+\mathrm{G}(2 \mathrm{df}, \mathrm{p})$ & -645.6216028 & - \\
\hline Pyridine-2-thyil & B3-MP2 & -645.0538964 & - \\
\hline Pyridine $^{\bullet+}$ & Opt : B3LYP/6-31+G(d,p) & -247.1935769 & 244.7613 \\
\hline Pyridine $^{\bullet+}$ & SP : PMP2/6-311+G(2df,p) & -247.3865247 & - \\
\hline Pyridine $^{\bullet+}$ & SP : B3LYP/6-311+G(2df,p) & -248.0285844 & - \\
\hline Pyridine $^{\bullet+}$ & B3-PMP2 & -247.7075546 & - \\
\hline${ }^{1} \mathrm{~S}$ & Opt : B3LYP/6-31+G(d,p) & -398.0448164 & 0 \\
\hline${ }^{1} \mathrm{~S}$ & $\mathrm{SP}: \mathrm{MP} 2 / 6-311+\mathrm{G}(2 \mathrm{df}, \mathrm{p})$ & -397.5480121 & - \\
\hline${ }^{1} \mathrm{~S}$ & $\mathrm{SP}: \mathrm{B} 3 \mathrm{LYP} / 6-311+\mathrm{G}(2 \mathrm{df}, \mathrm{p})$ & -398.0731365 & - \\
\hline${ }^{1} \mathrm{~S}$ & B3-MP2 & -397.8105743 & - \\
\hline
\end{tabular}

bond, $2.680 \AA$, and a shorter N(pyridine)-S bond, 1.759 $\AA$. In this species, the cyanogen chloride molecule belongs to the same plane as the pyridine ring, see Figure 4 . The main collision-induced decomposition of $\mathrm{m} / \mathrm{z} 111$ and 171 ions, namely the losses of a sulfur atom and of cyanogen chloride respectively, were calculated to require 518 and $373 \mathrm{~kJ} \mathrm{~mol}^{-1}$, and, therefore, $\mathrm{m} / \mathrm{z} 111$ and 171 ions, produced in the quadrupole, do not possess enough energy to decompose and are then observed.

It is obvious, from the energetic data presented in Figure 3 and Table 2, that the explanation of the different efficiencies of both reactions is not straightforward. This discrepancy probably originates from kinetic reasons. Indeed, the cycloaddition reaction representing a more complex pathway with bond formation, bond dissociation, cyclization... is likely to involve lower frequency factor transitions than the ionized sulfur transfer process and, as a consequence, is kinetically disfavored.

\section{Ion-molecule Reactions between NC-C $\equiv N^{+}-S^{*}$ Radical Cations and Pyridine}

Mass-selected $m / z 84$ radical cations, NC-C $\equiv \mathrm{N}^{+}-\mathrm{S}^{*}$, prepared by dissociative ionization of 3,4-dicyano-1,2,5- thiadiazole [21], also react with neutral pyridine in the quadrupole cell by (i) charge exchange reaction $(\mathrm{m} / \mathrm{z} 79)$ and subsequent production of protonated pyridine $(\mathrm{m} / \mathrm{z}$ 80), (ii) $\mathrm{NC}^{+}$cation transfer ( $\mathrm{m} / \mathrm{z}$ 105), (iii) ionized sulfur atom transfer $(\mathrm{m} / \mathrm{z} 111)$, and (iv) cycloaddition reaction $(\mathrm{m} / \mathrm{z}$ 162), see Table 1 and Figure 5 . The calculated ionization energy of NCCNS $(10.05 \mathrm{eV})$ [21] is in keeping with the observation of a very efficient charge exchange process $(33 \%$ of the main beam $+57 \%$ for protonated pyridine). When energetically allowed, the charge exchange reaction is known to present a very high efficiency because the measured reaction rate can be very close to the collision rate constant [27]. As a consequence, other reactions (even energetically competitives) can be kinetically occulted. In the present case, the reactions leading to $\mathrm{m} / \mathrm{z} 105,111$ and 162 ions, are accordingly disfavored although they are more exothermic. It is also important to mention that, relative to the previous case, both the reactions leading to $\mathrm{m} / \mathrm{z}$ 105 and 162 cations are less efficient when compared to the $\mathrm{S}^{*+}$ transfer reaction, see Table 1 and Figure 5a.

The CA spectrum of the $m / z 162$ cations, see Figure $5 \mathrm{~b}$, was found quite similar to the spectrum of the chlorinated $\mathrm{m} / \mathrm{z} 171$ cations previously recorded, see Figure $1 \mathrm{~b}$. The main dissociations of the collisionallyexcited $m / z 162$ ions are (i) the loss of $\mathrm{HCN}(m / z$ 135), (ii) 


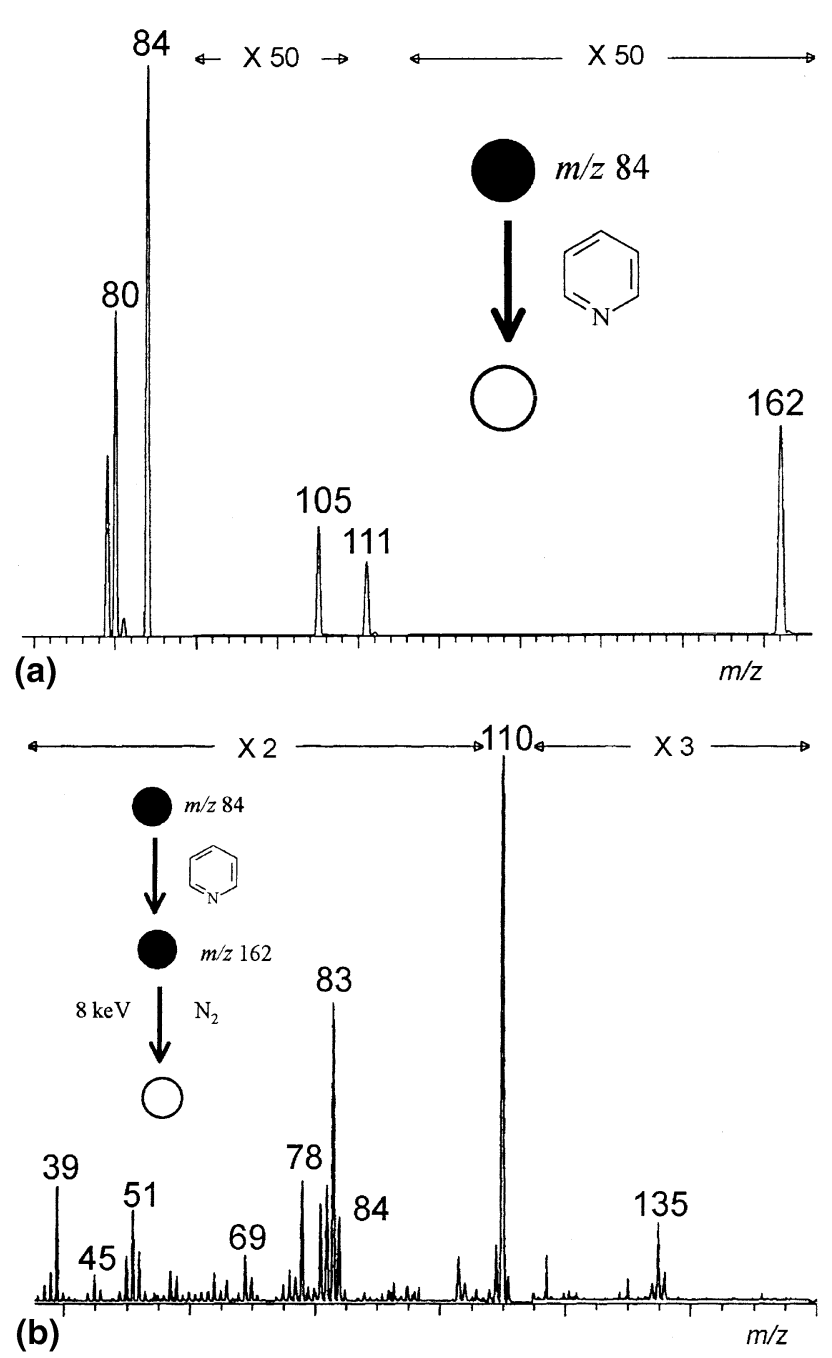

Figure 5. Associative ion-molecule reactions between mass-selected NC-C $\equiv \mathrm{N}^{+}-\mathrm{S}^{*+}(\mathrm{m} / \mathrm{z} 84)$ and neutral pyridine in the quadrupole collision cell: (a) mass spectrum of the reactions products (B scan), and (b) consecutive CA spectrum (linked scan, $8 \mathrm{keV}$ kinetic energy, $\mathrm{O}_{2}$ collision gas) of the $\mathrm{m} / \mathrm{z} 162$ ions.

the loss of cyanogen $(\mathrm{m} / \mathrm{z} 110)$, (iii) the loss of pyridine2-thyil radical $(\mathrm{m} / \mathrm{z} 84)$ and (iv) the loss of NCCNS $(\mathrm{m} / \mathrm{z}$ 78). The correspondence between these collision-induced reactions and those observed starting from the chlorinated species strongly suggests a structural analogy. Again, ab initio calculations reveal that cyanothiazolopyridinium, $3^{+}$, is a minimum on the potential energy surface, see Figure 4.

The potential energy diagram corresponding to the ion-molecule reactions is represented in Figure 6. In the present case, we limited ourselves to the calculation of the reactants and the products. Again both reactions are calculated to be exothermic with the ionized sulfur atom transfer reaction being energetically the most favorable process (344 vs. $300 \mathrm{~kJ} \mathrm{~mol}^{-1}$ ). Both ionmolecule reactions products are stable against decomposition since the fragmentations require about 339 and $518 \mathrm{~kJ} \mathrm{~mol}^{-1}$, respectively for the loss of cyanogen from $3^{+}$, and the loss of sulfur from $\mathbf{1}^{+}$, see Figure 6 .

\section{Ion-molecule reactions between $\mathrm{CH}_{3}-\mathrm{C} \equiv \mathrm{N}^{+}-\mathrm{S}^{*}$ Radical Cations and Pyridine}

The $\mathrm{CH}_{3}-\mathrm{C} \equiv \mathrm{N}^{+}-\mathrm{S}^{++}$radical cations were prepared by carbon disulfide chemical ionization of acetonitrile [28]. $\mathrm{CS}_{3}^{*+}$ ions were the reactive intermediates in this process $[28,29]$. The reactivity of acetonitrile $\mathrm{N}$-sulfide ions towards pyridine is found quite different in this last case, see Table 1. First, no cycloaddition ion-molecule reaction product is detected (expected mass-to-charge ratio at 151). However, this reaction is again calculated to be exothermic, $-100 \mathrm{~kJ} \mathrm{~mol}^{-1}$ (Table 2). Secondly, accordingly to the relative ionization energies, $9.25 \mathrm{eV}$ for pyridine and $8.44 \mathrm{eV}$ for $\mathrm{CH}_{3} \mathrm{CNS}$ [30], the charge exchange product, namely ionized pyridine, is not observed. Therefore, the intense signal recorded at $\mathrm{m} / \mathrm{z}$ 80 and corresponding to protonated pyridine truly originates from a protonation reaction of pyridine by the mass-selected reactive ions. The second observed reaction is the ionized sulfur atom transfer leading to $\mathbf{1}^{+}$ cations. This reaction is calculated to be $115 \mathrm{~kJ} \mathrm{~mol}^{-1}$ exothermic, see Tables 1 and 2 . The absence of the $\mathrm{m} / \mathrm{z}$ 151 signal can be explained on the basis of kinetic reasons: both the protonation and ionized sulfur atom transfer are too efficient and then probably consume the majority of the mass-selected reagent ions.

\section{Conclusions}

Ionized nitrile sulfide, $\mathrm{R}-\mathrm{C} \equiv \mathrm{N}^{+}-\mathrm{S}^{+}$, react with neutral pyridine (i) by ionized sulfur atom transfer and (ii) by an addition-hydrogen-atom elimination sequence of reactions respectively yielding ionized pyridine $N$-thioxide and a thiazolopyridinium cation. Both processes were experimentally studied using a large scale six sectors hybrid instrument presenting a sector-quadrupole-sector original geometry. The reaction pathways were then theoretically explored using ab initio calculations. Whereas the $\mathrm{S}^{++}$transfer reaction probably involves the intermediacy of two ion-molecule complexes, the thiazolopyridinium ion formation is likely to be initiated by an electrophilic attack of the $\mathrm{R}^{-\mathrm{C}^{+}}=\mathrm{N}-\mathrm{S}^{\circ}$ ion on the lone electron pair of pyridine, leading to a $\mathrm{C}-\mathrm{N}$ bond formation. This intermediate can then undergo an intramolecular radicalar substitution of an $\alpha$-hydrogen atom by the sulfur radical moiety, resulting in the formation of the bicyclic thiazolopyridinium cation. This process was qualitatively shown to be kinetically disfavored compared to the pyridine-S ions formation.

\section{Acknowledgments}

The Mons laboratory thanks the "Fonds National de la Recherche Scientifique" for its contribution to the acquisition of a large scale tandem mass spectrometer, Micromass AutoSpec 6F. P.G. also thanks the FNRS for a post doctoral fellowship and Professor Guy Bouchoux (Ecole Polytechnique de Palaiseau, France) for some help with the calculations. 


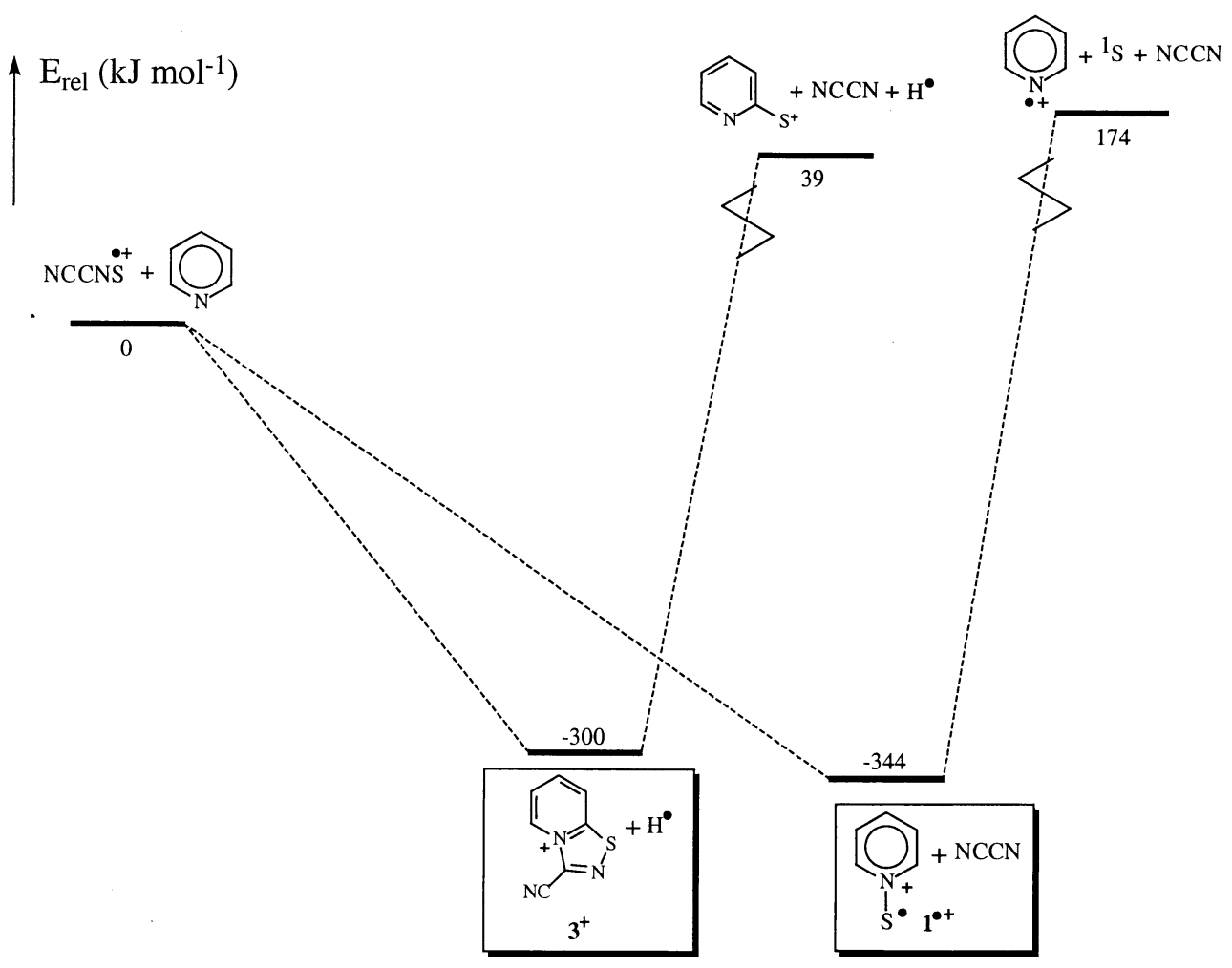

Figure 6. B3LYP/6-31+G(d,p) potential energy diagram for the $\mathrm{NCCNS}^{++} /$pyridine interaction . Relative energies are given in $\mathrm{kJ} \mathrm{mol}^{-1}$.

\section{References}

1. (a) Yates, B. F.; Bouma, W. J.; Radom, L. Detection of the prototype phosphonium $\left(\mathrm{CH}_{2} \mathrm{PH}_{3}\right)$, sulfonium $\left(\mathrm{CH}_{2} \mathrm{SH}_{2}\right)$, and chloronium $\left(\mathrm{CH}_{2} \mathrm{ClH}\right)$ ylides by neutralization-reionization mass spectrometry: a theoretical prediction. J. Am. Chem. Soc. 1984, 106, 5805. (b) Yates, B. F.; Bouma, W. J.; Radom, L. Distonic radical cations. Guidelines for the assessment of their stability. Tetrahedron 1986, 42, 6225.

2. Hammerum, S. Distonic radical cations in gaseous and condensed phase. Mass Spectrom. Rev. 1988, 7, 123.

3. Leeck, D. T.; Stirk, K. M.; Zeller, L. C.; Kiminkinen, L.K.M.; Castro, L. M.; Vainiotalo, P.; Kenttämaa, H. I. The long-lived radical cations of simple carbon esters isomerize to the lowestenergy structure. J. Am. Chem. Soc. 1994, 116, 3028.

4. (a) Gauld, J. W.; Audier, H. E.; Fossey, J.; Radom, L. Water-Catalyzed interconversion of conventional and distonic radical cations: methanol and methyleneoxonium radical cations. J. Am. Chem. Soc. 1996, 118, 6299. (b) Trikoupis, M. A.; Lavorato, D. J.; Terlouw, J. K.; Ruttink, P.J.A.; Burgers, P. C. Lowering large $1,2-\mathrm{H}$ shift barriers by proton-transfer catalysis: the challenging case of pyridine radical cation. Eur. Mass Spectrom 1999, 5, 431.

5. (a) Thoen, K. K.; Smith, R. L.; Nousiainen, J. J.; Nelson, E. D.; Kenttämaa, H. I. Charged phenyl radicals. J. Am. Chem. Soc 1996, 118, 8669. (b) Polasek, M.; Turecek, F.; Gerbaux, P.; Flammang, R. Nitrobenzene isomers. J. Phys. Chem. A 2001, 105, 995. (c) Trikoupis, M. A.; Gerbaux, P.; Lavorato, D. J.; Flammang, R.; Terlouw, J. K. The generation of H-shift isomers of hydroxypyridine: a combined experimental and computational investigation. Int. J. Mass. Spectrom 2002, 217, 1.

6. (a) Stirk, K. M.; Kiminkinen, L.K.M.; Kenttämaa, H. I. Ionmolecule reactions of distonic radical cations. Chem. Rev. 1992, 92, 1649. (b) Nelson, E. D.; Li, R.; Kenttämaa, H. I. Reactions of tert-butyl isocyanide with distonic radical cations. Int. J. Mass. Spectrom. 1999, 185/186/187, 91.

7. Nobes, R. H.; Bouma, W. J.; MacLeod, J. K.; Radom, L. The ionization of ethylene oxide. Chem. Phys. Lett. 1987, 135, 78.

8. $\mathrm{Yu}, \mathrm{S}$. J.; Gross, M. L.; Fountain, K. R. $\mathrm{CH}_{2}^{+}$Transfer to pyridine nucleophiles: a means of producing $\alpha$-distonic ions. J. Am. Soc. Mass Spectrom 1993, 4, 117.

9. Moraeas, L.A.B.; Eberlin, M.N. Acyclic distonic acylium ions: dual free radical and acylium ion reactivity in a single molecule. J. Am. Soc. Mass Spectrom 2000, 11, 697.

10. Eberlin, M. N.; Sorrilha, A.E.P.M.; Gozzo, F. C.; Pimpim, R. S. Novel [3+2] 1,3-cycloaddition of the ionized carbonyl ylide ${ }^{+} \mathrm{CH}_{2} \mathrm{OCH}_{2}$ with carbonyl compounds in the gas phase. J. Am. Chem. Soc. 1997, 119, 3550.

11. Gerbaux, P.; Barbieux-Flammang, M.; Flammang, R.; Bouchoux, G. Ion-molecule reactions between ionized nitrile oxides and neutral nitriles. Int. J. Mass. Spectrom 2002, 219, 643.

12. Gerbaux, P.; Wentrup, C.; Flammang, R. Mass Spectrometric Studies of Elusive Molecules that Contain an $\mathrm{N}^{+}-\mathrm{X}^{-}$Bond. Mass Spectrom. Rev. 2000, 19, 367.

13. (a) Bateman, R. H.; Brown, J.; Lefevere, M.; Flammang, R.; Van Haverbeke, Y. Applications in gaseous ion and neutral chemistry using a 6-sector mass spectrometer. Int. J. Mass. Spectrom. Ion Process 1992, 115, 205. (b) Flammang, R.; Van Haverbeke, Y.; Braybrook, C.; Brown, J. A new hybrid mass spectrometer for the investigation of ion/molecule reactions. Rapid Commun. Mass Spectrom 1995, 9, 975.

14. Mørkved, E. V.; Kjøsen, H.; Neset, S. M. Reactions of 1,2,5thiadiazole-3,4-dicarbonitrile. Acta Chem. Scand. 1994, 48, 372.

15. Gaussian 98: Frisch M. J.; Trucks G. W.; Schlegel H. B.; Scuserai G. E.; Robb M. A.; Cheeseman J. R.; Zakrzewski V. G.; Montgomery J. A.; Stratmann R. E.; Burant J. C.; Dapprich S.; Millam J. M.; Daniels A. D.; Kudin K. N.; Strain M. C.; Farkas 
O.; Tomasi J.; Barone V.; Cossi M.; Cammi R.; Mennucci B.; Pomelli C.; Adamo C.; Clifford S.; Ochterski J.; Petersson G. A.; Ayala P. Y.; Cui Q.; Morokuma K.; Malick D. K.; Rabuck A. D.; Raghavachari K.; Foresman J. B.; Cioslowski J.; Ortiz J. V.; Stefanov B. B.; Liu B. B.; Liashenko A.; Piskorz P.; Komaromi A.; Gomperts R.; Martin R. L.; Fox D. J.; Keith T.; Al-Laham M. A.; Peng C. Y.; Nanayakkara M. W.; Gonzalez C.; Challacombe M.; Gill P.M.W.; Johnson B. G.; Chen W.; Wong M. W.; Andres J. L.; Head-Gordon M.; Reploge E. S.; Pople J. A. Gaussian, Inc., Pittsburg PA, 1998.

16. (a) Schlegel, H. B. Potential energy curves using unrestricted Møller-Plesset perturbation theory with spin annihilation. J. Chem. Phys 1986, 84, 4530. (b) Mayer, I. The spin-projected extended Hartree-Fock method. Adv. Quantum Chem 1980, 12, 189.

17. Polasek, M.; Turecek, F. Hydrogen atom adducts to nitrobenzene: formation of the phenylnitronic radical in the gas phase and energetics of Wheland intermediates. J. Am. Chem. Soc. 2000, 122, 9511.

18. Rassolov, V. A.; Ratner, M. A.; Pople, J. A. Electron correlation in chemical bonds. J. Chem. Phys. 2000, 112, 4014.

19. Gerbaux, P.; Van Haverbeke, Y.; Flammang, R. Ion-molecule reaction of pyridine with $\mathrm{CS}_{3}$ radical cations: experimental evidence for the production of pyridine $\mathrm{N}$-thioxide distonic ions. J. Mass Spectrom. 1997, 32, 1170.

20. Gerbaux P. Ion-molecule reactions in the gas phase of a new hybrid mass spectrometer. Ph.D. Thesis, University of MonsHainaut, Belgium, 1999.

21. Flammang, R.; Gerbaux, P.; Mørkved, E. V.; Wong, M. W.; Wentrup, C. Generation of new nitrile $N$-sulfides (NCCNS, $\mathrm{R}_{2} \mathrm{NCCNS}, \mathrm{CH}_{3} \mathrm{SCNS}$ and $\mathrm{ClCNS}$ ) as ions and neutrals in the gas phase: tandem mass spectrometry, flash vacuum pyrolysis and ab initio MO study. J. Phys. Chem. 1996, 100, 17452.

22. Eberlin, M. N.; Kotiaho, T.; Shay, B. J.; Yang, S. S.; Cooks, R. G. Gas-phase $\mathrm{Cl}^{+}$affinities of pyridines determined by the ki- netic method using multiple-stage (MS ${ }^{3}$ ) mass spectrometry. J. Am. Chem. Soc. 1994, 116, 2457.

23. Lias, S. G.; Bartmess, J. E.; Liebman, J. F.; Holmes, J. L.; Levin, R. D.; Mallard, W. G. Gas-phase ion and neutral thermochemistry. J. Phys. Chem., Reference Data 1988, 17.

24. Carvalho, M. C.; Juliano, V. F.; Kascheres, C.; Eberlin, M. N. Gas phase chemistry of the heterocumulene cations $\mathrm{O}=\mathrm{C}=\mathrm{N}^{+}=\mathrm{C}=\mathrm{O}$ and $\mathrm{O}=\mathrm{C}=\mathrm{C}=\mathrm{N}^{+}=\mathrm{O}$. J. Chem. Soc. Perkin Trans. $1997,2,1$.

25. De Koster, C. G.; Van Houte, J. J.; Van Thuijl, J. Gas phase substitution reactions by radical cations. I. Reaction of the C-C ring-opened oxirane radical cation with pyridine. Int. J. Mass Spectrom. Ion Process. 1990, 98, 235.

26. Stirk, K. M.; Smith, R. L.; Orlowski, J. C.; Kenttämaa, H. I. Bimolecular reactions involving the radical site of the distonic ion ${ }^{\circ} \mathrm{CH}_{2} \mathrm{CH}_{2} \mathrm{CH}_{2} \mathrm{C}^{+} \mathrm{O}$. Rapid Commun. Mass Spectrom. 1993, 7 , 392.

27. Harrison A. G. Chemical Ionization Mass Spectrometry, CRC Press, Boca Raton, Florida 1983, p 13.

28. Gerbaux, P.; Flammang, R.; Van Haverbeke, Y.; Wong, M. W.; Wentrup, C. Generation of nitrile $N$-sulfide (RCNS) radical cations and neutrals via ion-molecule reactions: tandem mass spectrometry and ab initio MO study. J. Phys. Chem. 1997, 101, 6970.

29. Praet, M. T.; Delwiche, J. P. Ion-molecule reactions in $\mathrm{CS}_{2}$ and COS studied by 'Time-of-Flight' mass spectrometry. Adv. Mass Spectrom. 1974, 6, 829

30. King, M. A.; Kroto, H. W. He I Photoelectron study of cyanogen isothiocyanate, NCNCS, produced by thermal isomerization of sulfur dicyanide, $\mathrm{S}(\mathrm{CN})_{2}$. J. Am. Chem. Soc. 1984, 106, 7347.

31. Schwartz, J. C.; Wade, A. P.; Enke, C. G.; Cooks, R. G. Systematic delineation of scan modes in multidimensional mass spectrometry. Anal. Chem. 1990, 62, 1809. 